\title{
Epidemiology of diabetes and complications among adults in the Republic of Ireland 1998-2015: a systematic review and meta-analysis
}

\author{
Marsha L. Tracey ${ }^{1 *}$, Michael Gilmartin², Kate O’Neill', Anthony P. Fitzgerald', Sheena M. McHugh ${ }^{1}$,
} Claire M. Buckley ${ }^{1,3}$, Ronan J. Canavan ${ }^{4}$ and Patricia M. Kearney ${ }^{1}$

\begin{abstract}
Background: Accurate estimates of the burden of diabetes are essential for future planning and evaluation of services. In Ireland, there is no diabetes register and prevalence estimates vary. The aim of this review was to systematically identify and review studies reporting the prevalence of diabetes and complications among adults in Ireland between 1998 and 2015 and to examine trends in prevalence over time.

Methods: A systematic literature search was carried out using PubMed and Embase. Diabetes prevalence estimates were pooled by random-effects meta-analysis. Poisson regression was carried out using data from four nationally representative studies to calculate prevalence rates of doctor diagnosed diabetes between 1998 and 2015 and was also used to assess whether the rate of doctor diagnosed diabetes changed over time.

Results: Fifteen studies (eight diabetes prevalence and seven complication prevalence) were eligible for inclusion. In adults aged 18 years and over, the national prevalence of doctor diagnosed diabetes significantly increased from $2.2 \%$ in 1998 to $5.2 \%$ in 2015 ( $p_{\text {trend }} \leq 0.001$ ). The prevalence of diabetes complications ranged widely depending on study population and methodology used (6.5-25.2 \% retinopathy; 3.2-32.0 \% neuropathy; $2.5-5.2 \%$ nephropathy).

Conclusions: Between 1998 and 2015, there was a significant increase in the prevalence of doctor diagnosed diabetes among adults in Ireland. Trends in microvascular and macrovascular complications prevalence could not be examined due to heterogeneity between studies and the limited availability of data. Reliable baseline data are needed to monitor improvements in care over time at a national level. A comprehensive national diabetes register is urgently needed in Ireland.
\end{abstract}

Keywords: Ireland, Prevalence, Trends, Diabetes, Microvascular, Macrovascular, Adults, Epidemiology

\section{Background}

Diabetes is a serious global public health issue which has been described as the most challenging health problem in the $21^{\text {st }}$ century $[1,2]$. Cases of diabetes have progressively increased worldwide; between 1980 and 2008 there was a two-fold increase in the number of adults with diabetes [3]. Type 2 diabetes is the main driver of the epidemic, accounting for approximately

\footnotetext{
* Correspondence: m.treacy@ucc.ie

'Department of Epidemiology and Public Health, University College Cork,

Western Gateway Building, Cork, Republic of Ireland

Full list of author information is available at the end of the article
}

$90 \%$ of all cases [2]. The increasing burden of diabetes is driven primarily by rising levels of obesity and an ageing population $[2,4]$. To date there is no national surveillance programme, or national population-based survey of diabetes in Ireland. Therefore it is difficult to quantify or monitor the impact of diabetes at a national level. Estimates from the International Diabetes Federation (2013) suggest that the prevalence of diabetes is in line with global trends. In 2000, the IDF estimated that the prevalence of diabetes was $3.2 \%$ [5], this had increased to $6.5 \%$ in 2013 [2]. 
Diabetes places a significant burden of care on the individual, health care professionals and the wider health system $[1,6]$. Individuals with diabetes are two to four times more likely to develop cardiovascular disease relative to the general population and have a two to five-fold greater risk of dying from these conditions [7, 8]. Diabetes is a significant cause of blindness in adults, nontraumatic lower limb amputations and end-stage renal disease resulting in transplantation and dialysis [2].

Understanding the epidemiology of diabetes is essential to identify public health priorities. Accurate estimates of the burden of diabetes are essential for future planning and evaluation of services. While the IDF provides prevalence estimates for countries and regions, there are substantial variations in time trends as estimates are based on imputations $[9,10]$. To date, estimates of diabetes prevalence in Ireland have been largely based on data from the 2007 National Survey of Health and Lifestyles in Ireland (SLÁN) [11]. Country specific prevalence rates have also been reported in the grey literature [2]; however these estimates have been extrapolated using data from the UK. The Euro Diabetes Index (2014) stated that there was a lack of reliable data to monitor diabetes related complications in Ireland [12]. To date, a comprehensive overview of the diabetes situation in Ireland has not been carried out. Therefore the rationale for carrying out this systematic review is to provide a comprehensive understanding of the diabetes situation in Ireland and to highlight current gaps in existing knowledge to inform future research. The aims of this review are (1) to systematically identify and summarise studies describing the prevalence of diabetes and the most common microvascular (retinopathy, neuropathy and nephropathy) and macrovascular complications among adults in Ireland between 1998 and 2014; and (2) to explore trends in diagnosed diabetes prevalence between 1998 and 2015.

\section{Methods}

This review was produced according to Preferred Reporting Items for Systematic reviews and Meta-Analyses (PRISMA) guidelines for systematic reviews and metaanalyses [13]. Key words and study eligibility criteria were determined a priori.

\section{Search strategy}

Both peer-reviewed journal articles and reports were considered for this review. A systematic literature search was carried out in PubMed and Embase databases to identify relevant studies reporting the prevalence of diabetes, microvascular or macrovascular complications among adults within the Republic of Ireland. Keywords and Medical Subject Headings (MeSH) terms included Ireland, prevalence, diabetes, microvascular, retinopathy, neuropathy, nephropathy, macrovascular and cardiovascular disease. Keywords were combined using the AND or OR operators (Additional file 1). Titles and abstracts of the resulting literature were screened for further consideration. Reference lists of articles were also examined to identify potentially relevant studies. In addition, a Google search was conducted using the keywords prevalence, diabetes, retinopathy, neuropathy, nephropathy and Ireland to identify relevant grey literature. Searches were carried out between January 2014 and March 2014. A second search was carried out in December 2015 to ensure the review included all up to date relevant information.

\section{Inclusion criteria}

Studies were eligible for inclusion if they met the following criteria: (1) conducted in the Republic of Ireland between 1998 and 2014; (2) cross-sectional study design or baseline data from longitudinal studies; (3) prevalence estimates reported for adults aged $\geq 18$ years, including men and women; (4) data provided on diabetes prevalence (including a self-report of a previous doctor diagnosis and undiagnosed diabetes) and/or the prevalence of microvascular complications (retinopathy, neuropathy, nephropathy) or macrovascular complications (myocardial infarction, congestive heart failure, stroke or TIA) in persons with diabetes; (5) if prevalence data were not reported, sufficient detail to calculate the numerator and denominator was provided; (6) the total sample size was $\geq 200$; (7) adequate information was reported on the methods used.

\section{Exclusion criteria}

Studies containing participants from Northern Ireland, restricted to a specific sub-population (including hospitalbased studies), solely focused on type 1 diabetes, prediabetes or gestational diabetes were excluded from this review. Model estimates of prevalence were also excluded. If multiple articles provided information on a single study, the article detailing the most comprehensive data was selected. Full text articles were retrieved for all potentially eligible studies and were independently reviewed by three authors (MT, MG, and $\mathrm{KON}$ ).

\section{Data abstraction and quality assessment}

For each eligible study, three reviewers (MT, MG, and $\mathrm{KON}$ ) individually collected relevant information using a structured data extraction form. The methodological quality of each included study was assessed using a critical appraisal checklist for studies used in systematic reviews addressing questions of prevalence [14]. This appraisal tool was developed to specifically examine the internal and external validity of prevalence data included in systematic reviews. Methodological quality was considered 'low' if three or less criteria were met, 'moderate' if four to six criteria were met and 'high' if seven to nine criteria 
were met. Articles were not excluded on the basis of quality. Any inconsistencies in data abstraction and quality assessment between reviewers were resolved through consensus.

\section{Statistical analysis}

A meta-analysis was carried out using STATA version 13.1 (StataCorp, College Station, TX, USA). Studies were grouped into four categories: diagnosed diabetes among adults aged 18+ years; diagnosed and undiagnosed diabetes among adults aged $45+$ years; diagnosed diabetes among adults aged 45+ years; undiagnosed diabetes among adults aged $45+$ years. Pooled estimates of diabetes prevalence and $95 \%$ confidence intervals (95\% CI) were calculated. Trends in pooled prevalence could not be explored as there was a lack of available data from different time points; therefore an overall estimate was provided for each group. Heterogeneity between studies was assessed by the Chi-square based $\mathrm{Q}$ test and $\mathrm{I}^{2}$ statistic. Potential publication bias was evaluated by the Begg's test. A two-tailed $p<0.05$ was regarded to be statistically significant. High heterogeneity was found among studies reporting diabetes prevalence $\left(\mathrm{I}^{2} \geq 75 \%\right.$, p-value $\left.<0.01\right)$ hence, pooled estimates were calculated using random-effects model using the method of DerSimonian and Laird [15]. The results from the meta-analysis were presented in a forest plot. To determine the robustness of the results, a sensitivity analysis, based on high quality studies, was carried out. A meta-analysis of the prevalence of diabetes complications was inappropriate; factors which influence prevalence estimates (e.g. time since diabetes diagnosis, type of diabetes, method of diagnosis) either varied between studies or were not reported. Instead a narrative synthesis provides a summary of relevant data.

\section{Trends in diagnosed diabetes}

As trends in diabetes prevalence could not be calculated by meta-analysis, original datasets from four national population based studies [16-19], identified during the literature search were obtained and analysed. In each dataset, diabetes was defined by a self-report of a previous doctor diagnosis. A detailed description on study methodology can be found elsewhere [18, 20]. Using data from these national surveys, multivariate Poisson regression models were undertaken to impute annual gender and age-specific (18-39 years, $40-69$ years, $\geq 70$ years) rates of diagnosed diabetes and to assess trends over time. The dependent variable was the number of cases of diagnosed diabetes and the exposure variables were year of data collection and age group. An interaction term between calendar year and age group was considered to explore whether the rates of change over time differed across age groups; a non-significant interaction indicated a common linear trend in prevalence. The predict command was used post analysis to calculate the expected rates of diagnosed diabetes for each calendar year of the study. The gender and age-specific predicted rates were applied to 2004-2015 population data so the absolute number of diabetes cases could be obtained. Annual population estimates were obtained from the Central Statistics Office (CSO), Ireland [21]. A census took place in Ireland in 2002, 2006 and 2011; data for other study years were CSO inter-censal estimates [21]. Prevalence was calculated by dividing the number of expected cases of doctor diagnosis of diabetes by the total study population and was expressed as a percentage with $95 \% \mathrm{CI}$. Prevalence estimates were presented graphically in Excel.

\section{Results}

\section{Study selection}

Results of the literature search and the selection process are summarised in Fig. 1. One report [22] provided two estimates for diabetes prevalence from two separate studies [16, 17]. In total, 15 studies were eligible for inclusion; eight reporting estimates on diabetes prevalence and seven reporting estimates on complication prevalence. Of the included studies, the methodological quality was considered moderate in nine studies and high in the remaining studies (Additional file 2).

\section{Characteristics of selected studies}

Characteristics of studies that reported the prevalence of diabetes or diabetes complications are presented in Tables 1 and 2. In all included studies, data collection were carried out between 1998 and 2011. Studies varied in terms of the study design, setting (national vs. regional), sampling approach and study quality. Of the 8 studies reporting on diabetes prevalence (Table 1), five articles had been published in peer-reviewed journals [11, 23-26], while three estimates were reported in two national reports $[22,27]$. Of the 7 studies reporting diabetes complications (Table 2), six had been published in peerreviewed journals [28-33], while one audit [34] provided data on the prevalence of diabetes related complications. Five studies utilised an objective data source to ascertain the prevalence of complications [28-30,33,34]. The diagnostic criteria for complications was unclear in three studies [31, 31, 34] whereas the remaining four used validated diagnostic criteria to identify cases [28-30, 33], however these criteria differed between studies reporting on the same complication.

\section{Prevalence of diabetes in included studies}

Table 3 reports the prevalence of diabetes by study. Individual and summary estimates, based on a random-effects meta-analysis are illustrated in Fig. 2. There was significant heterogeneity in all groups. Sensitivity analysis only 


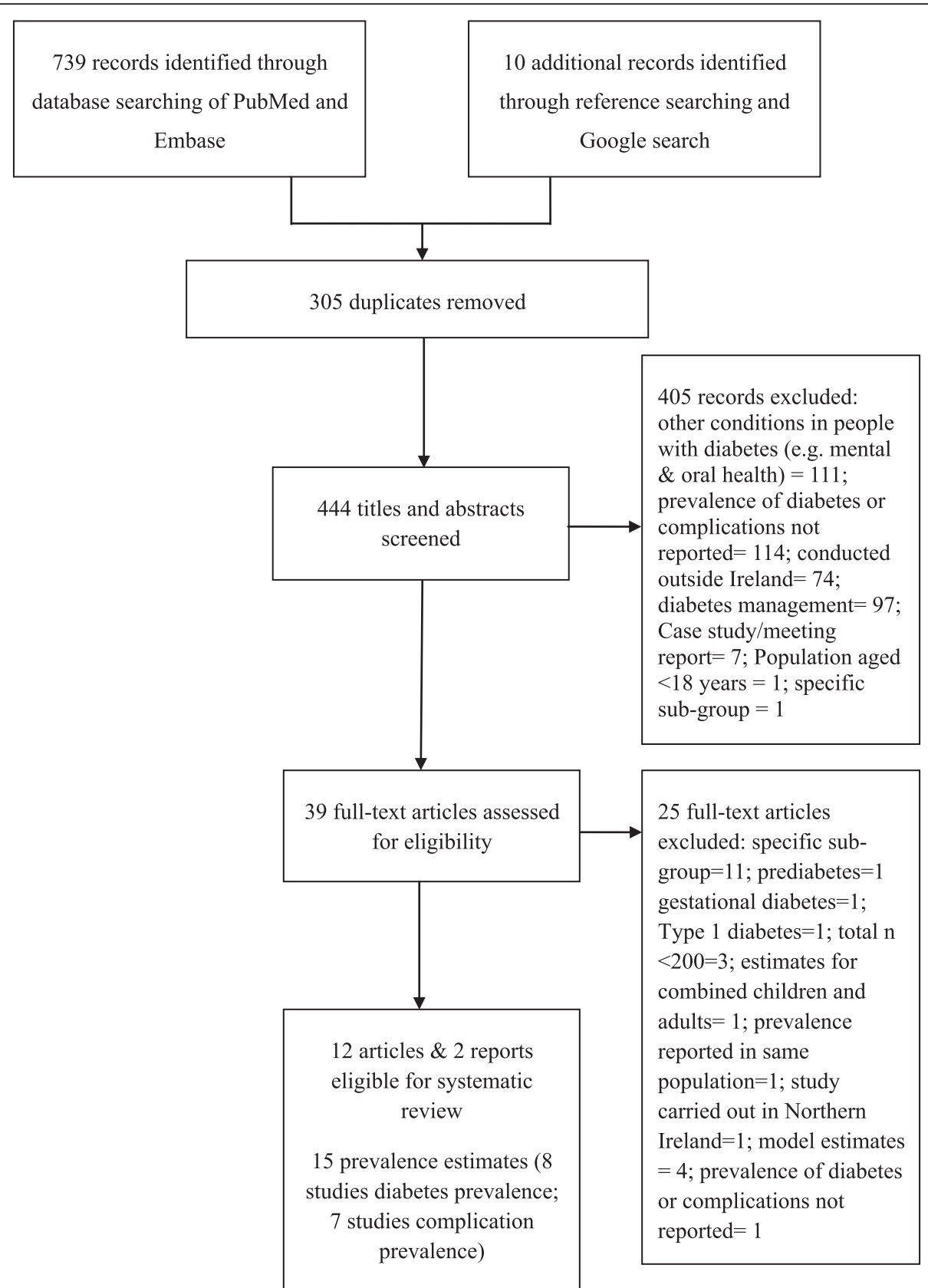

Fig. 1 PRISMA flow chart depicting the selection process of articles included in the systematic review

showed lower heterogeneity in combined prevalence rates for undiagnosed and diagnosed diabetes among adults aged over 45 years $\left(\mathrm{I}^{2} \geq 25 \%, p=0.36\right)$; with a pooled prevalence of $9.2 \%$ (95\% CI: 8.6-9.8) (Additional file 3). According to the Egger's test, there was no evidence of publication bias $(p=0.27)$.

Trends in the prevalence of diagnosed diabetes over time In adults aged 18 years and over, the prevalence of diagnosed diabetes increased from $2.2 \%$ (95 \% CI: $1.7 \%-$
$2.7 \%$ ) in 1998 to $5.2 \%$ (95\% CI: $5.1 \%-5.3 \%$ ) in 2015 $\left(p_{\text {trend }}=<0.001\right)$; representing an absolute mean increase of $0.17 \%$ per year. In 2015 , the incidence of diagnosed diabetes was $0.2 / 100$ population.

Figure 3 illustrates the age-specific prevalence of selfreported diagnosed diabetes from 1998 to 2015. In adults aged between 18 and 39 years, the prevalence of selfreported doctor diagnosed diabetes remained stable between 1998 and 2015 in both men and women; $p_{\text {trend }}>0.05$. However, there was a significant increase in 
Table 1 Characteristics of studies reporting the prevalence of diabetes or related complications among adults in the Republic of Ireland, $1998-2011$

\begin{tabular}{|c|c|c|c|c|c|c|c|c|c|c|c|}
\hline Author & $\begin{array}{l}\text { Year of data } \\
\text { collection }\end{array}$ & Study design & $\begin{array}{l}\text { National or } \\
\text { regional }\end{array}$ & Setting & Population & Sampling frame & Sampling method & Sample size & $\begin{array}{l}\text { Males } \\
(\%)\end{array}$ & $\begin{array}{l}\text { Age } \\
\text { (years) }\end{array}$ & $\begin{array}{l}\text { Study quality } \\
\text { (out of 9) }\end{array}$ \\
\hline \multicolumn{12}{|l|}{ Diabetes prevalence } \\
\hline $\begin{array}{l}\text { Sheily and } \\
\text { Kelleher [22] }\end{array}$ & 1998 & Cross-sectional & National & Household & General population & Electoral register & Multistage sample & 1632 & 47.7 & 55 & 7 \\
\hline $\begin{array}{l}\text { Creagh } \\
\text { et al. [23] }\end{array}$ & 1998 & Cross-sectional & Regional & 17 GP practices & Primary Care Patients & Practice list & Stratified random & 1018 & 48.2 & $50-69$ & 6 \\
\hline $\begin{array}{l}\text { Census Statistic } \\
\text { Office (CSO) [27] }\end{array}$ & 2001 & Survey & National & Household & General population & Census & Total sample & 3917203 & - & 18 & 5 \\
\hline $\begin{array}{l}\text { Sheily and } \\
\text { Kelleher [22] }\end{array}$ & 2002 & Cross-sectional & National & Household & General population & Electoral register & Multistage sample & 1745 & 41.7 & 55 & 7 \\
\hline $\begin{array}{l}\text { Balanda } \\
\text { et al. [11] }\end{array}$ & 2007 & Cross-sectional & National & Household & General population & Geodirectory & Multistage probability & 10,364 & 49.5 & 18 & 8 \\
\hline $\begin{array}{l}\text { Gallagher } \\
\text { et al. [24] }\end{array}$ & $2009-2010$ & Cross-sectional & National & Database & $\begin{array}{l}\text { Patients covered by } \\
\text { GMS, LTI, DPS schemes }\end{array}$ & $\begin{array}{l}\text { HSE-PCRS pharmacy } \\
\text { claims data base }\end{array}$ & $\begin{array}{l}\text { Total sample } \\
2009 \\
2010\end{array}$ & $\begin{array}{l}3493974 \\
3490877\end{array}$ & - & 16 & 6 \\
\hline Leahy et al. [25] & 2009-2011 & $\begin{array}{l}\text { Cross-sectional } \\
\text { analysis of } \\
\text { longitudinal } \\
\text { study }\end{array}$ & National & $\begin{array}{l}\text { Household \& } \\
\text { designated } \\
\text { health centre }\end{array}$ & General population & Geodirectory & Multi-stage probability & 5377 & 46.5 & 50 & 8 \\
\hline $\begin{array}{l}\text { OConnor } \\
\text { et al. [26] }\end{array}$ & 2010-2011 & Cross-sectional & Regional & Primary care centre & Patients & Practice list & Random & 2047 & 49.2 & $50-69$ & 8 \\
\hline
\end{tabular}


Table 2 Characteristics of studies reporting the prevalence of diabetes or complications among adults in the Republic of Ireland, 1998-2011

\begin{tabular}{|c|c|c|c|c|c|c|c|c|c|c|c|}
\hline Author & $\begin{array}{l}\text { Year of data } \\
\text { collection }\end{array}$ & Study design & $\begin{array}{l}\text { National or } \\
\text { regional }\end{array}$ & Setting & Population & Sampling frame & Sampling method & $\begin{array}{l}\text { Sample } \\
\text { size }\end{array}$ & $\begin{array}{l}\text { Males } \\
(\%)\end{array}$ & $\begin{array}{l}\text { Age } \\
\text { (years) }\end{array}$ & $\begin{array}{l}\text { Study quality } \\
\text { (out of 9) }\end{array}$ \\
\hline \multicolumn{12}{|l|}{$\begin{array}{l}\text { Complication } \\
\text { prevalence }\end{array}$} \\
\hline $\begin{array}{l}\text { Kelliher } \\
\text { et al. [28] }\end{array}$ & 2003 & Cross-sectional & National & $\begin{array}{l}\text { National Council } \\
\text { for Blind Ireland } \\
\text { (NCBI) }\end{array}$ & $\begin{array}{l}\text { All person registered } \\
\text { blind }\end{array}$ & NCBI database & Total sample & 6826 & - & Adults & 8 \\
\hline $\begin{array}{l}\text { Buckley } \\
\text { et al. [29] }\end{array}$ & 2009 & Cross-sectional & National & Population & People with diabetes & $\begin{array}{l}\text { Hospital In-Patient } \\
\text { Enquiry (HIPE) dataset }\end{array}$ & Total sample & 723551 & - & 20 years & 9 \\
\hline $\begin{array}{l}\text { Marsden } \\
\text { et al. [34] }\end{array}$ & $2008-2009$ & Audit & Regional & $\begin{array}{l}20 \text { general } \\
\text { practices }\end{array}$ & $\begin{array}{l}\text { Patients with T1 \& T2 DM } \\
\text { registered with diabetes } \\
\text { structure care programme }\end{array}$ & Practice patient list & $\begin{array}{l}\text { Every second } \\
\text { person from list }\end{array}$ & 1071 & 51.9 & $\begin{array}{l}63(\mathrm{sd} \\
13)\end{array}$ & 5 \\
\hline $\begin{array}{l}\text { Hurley } \\
\text { et al. [30] }\end{array}$ & 2008-2009 & $\begin{array}{l}\text { Cross-sectional } \\
\text { analysis of } \\
\text { longitudinal study }\end{array}$ & Regional & $\begin{array}{l}\text { General } \\
\text { practices with } \\
\text { diabetes nurse }\end{array}$ & Patients with T1 \& T2 DM & $\begin{array}{l}\text { Practice diabetes } \\
\text { register }\end{array}$ & $\begin{array}{l}\text { Researchers selected } \\
\text { eligible participants }\end{array}$ & 563 & 60 & $\begin{array}{l}64(\mathrm{sd} \\
13.4)\end{array}$ & 6 \\
\hline $\begin{array}{l}\text { Farrell \& } \\
\text { Moran [31] }\end{array}$ & 2010 & Cross-sectional & Regional & $\begin{array}{l}30 \text { general } \\
\text { practices }\end{array}$ & T2 DM & $\begin{array}{l}\text { Diabetes imitative } \\
\text { database }\end{array}$ & Stratified sampling & 309 & - & - & 5 \\
\hline $\begin{array}{l}\text { Tracey } \\
\text { et al. [32] }\end{array}$ & $2009-2011$ & $\begin{array}{l}\text { Cross-sectional } \\
\text { analysis of } \\
\text { longitudinal study }\end{array}$ & National & Household & General population & Geodirectory & $\begin{array}{l}\text { Multi-stage } \\
\text { probability }\end{array}$ & 8175 & 53 & 50 & 8 \\
\hline $\begin{array}{l}\text { McHugh } \\
\text { et al. [33] }\end{array}$ & 2011 & Cross-sectional & Regional & $\begin{array}{l}30 \text { general } \\
\text { practices }\end{array}$ & Patients with T1 \& T2 DM & Practice patient list & $\begin{array}{l}\text { All persons with } \\
\text { T1\&T2DM invited }\end{array}$ & 1542 & 57.3 & $\begin{array}{l}65(s d \\
13)\end{array}$ & 7 \\
\hline
\end{tabular}


Table 3 Prevalence of diabetes among adults in included studies, 1998-2011

\begin{tabular}{|c|c|c|c|c|c|c|c|c|c|c|}
\hline \multirow[t]{2}{*}{ Study } & \multirow{2}{*}{$\begin{array}{l}\text { Year of data } \\
\text { collection }\end{array}$} & \multirow{2}{*}{$\begin{array}{l}\text { Response } \\
\text { rate (\%) }\end{array}$} & \multirow[t]{2}{*}{ Sample size } & \multirow[t]{2}{*}{ Age } & \multirow{2}{*}{$\begin{array}{l}\text { Diabetes } \\
\text { type }\end{array}$} & \multirow[t]{2}{*}{ Diagnostic criteria } & \multirow[t]{2}{*}{ Estimate } & \multicolumn{3}{|c|}{ Prevalence \% (95 \% Cl) } \\
\hline & & & & & & & & Males & Females & Total \\
\hline $\begin{array}{l}\text { Sheily and } \\
\text { Kelleher [22] }\end{array}$ & 1998 & 62 & 1632 & 55 years & All & $S R^{a}$ & Diagnosed & 6.1 & 4.3 & 5.4 \\
\hline Creagh et al. [23] & 1998 & 69.1 & 1018 & $50-69$ years & 2 & $F P G^{b}$ & $\begin{array}{l}\text { Diagnosed } \\
\text { Undiagnosed } \\
\text { Total } \\
\text { Total } 65 \text { years }\end{array}$ & $\begin{array}{l}- \\
- \\
- \\
13\end{array}$ & $\begin{array}{l}- \\
- \\
- \\
7\end{array}$ & $\begin{array}{l}2.8 \\
1.2 \\
3.9(2.9-5.4) \\
-\end{array}$ \\
\hline CSO [27] & July-Sept. 2001 & - & 3917203 & 18 years & All & SR & $\begin{array}{c}\text { Diagnosed } \\
18 \text { years } \\
65 \text { years }\end{array}$ & - & - & $\begin{array}{l}1.5 \\
4.5\end{array}$ \\
\hline $\begin{array}{l}\text { Sheily and } \\
\text { Kelleher [22] }\end{array}$ & 2002 & 53 & 1745 & 55 years & All & SR & Diagnosed & 8.0 & 5.1 & 6.4 \\
\hline Balanda et al. [11] & 2007 & 62 & 10,364 & 18 years & All & $\begin{array}{l}\text { SR or medication use } \\
\text { or } \mathrm{HbAlc}^{\mathrm{C}}\end{array}$ & $\begin{array}{l}\text { Diagnosed } \\
18-44 \text { years } \\
45+\text { years } \\
\text { Total } 18 \text { years } \\
\text { Undiagnosed ( } 45 \text { years) } \\
\text { Total (diagnosed \& undiagnosed } \\
\quad 45 \text { years) }\end{array}$ & $\begin{array}{l}- \\
6.8(5.7-7.9) \\
- \\
4.0(1.6-6.3) \\
10.8(8.2-13.4)\end{array}$ & $\begin{array}{l}- \\
5.4(4.3-6.6) \\
- \\
1.7(0.3-3.0) \\
7.1(5.3-8.9)\end{array}$ & $\begin{array}{l}0.7(0.5-0.9) \\
6.1(5.5-6.9) \\
3.5(3.1-3.9) \\
2.8(1.4-4.1) \\
8.9(7.3-10.5)\end{array}$ \\
\hline $\begin{array}{l}\text { Gallagher et al. } \\
\text { [24] }\end{array}$ & $\begin{array}{l}2009 \\
2010\end{array}$ & - & $\begin{array}{l}3493974 \\
3490877\end{array}$ & 18 years & 2 & $\begin{array}{l}\text { At least } 1 \text { prescription } \\
\text { of diabetes medication }\end{array}$ & $\begin{array}{l}\text { Diagnosed } \\
2009 \\
2010\end{array}$ & - & $\begin{array}{l}- \\
-\end{array}$ & $\begin{array}{l}2.8 \\
3.1\end{array}$ \\
\hline Leahy et al. [25] & 2009-2011 & 62 & 5377 & 50 years & 2 & $\begin{array}{l}\text { SR or medication use } \\
\text { or } \mathrm{HbA1c^{c }}\end{array}$ & $\begin{array}{l}\text { Diagnosed } \\
\text { Undiagnosed } \\
\text { Total (diagnosed \& undiagnosed) } \\
50-59 \text { years } \\
60-69 \text { years } \\
70-79 \text { years } \\
80+\text { years }\end{array}$ & $\begin{array}{l}- \\
- \\
11.8(10.3-13.3)^{*} \\
5.1(4.0-7.0) \\
6.0(5.0-8.0) \\
12.0(8.0-14.0) \\
10.0(5.0-15.0)\end{array}$ & $\begin{array}{l}- \\
- \\
7.3(6.0-8.5)^{*} \\
4.0 \\
14.0(11.0-16.0) \\
17.0(14.0-21.0) \\
25.0(15.0-36.0)\end{array}$ & $\begin{array}{l}8.6(7.6-9.5) \\
0.9(0.6-1.1) \\
9.5(8.5-10.4) \\
5.0(4.0-6.0) \\
- \\
- \\
16.0(10.7-21.4)\end{array}$ \\
\hline $\begin{array}{l}\text { OConnor et al. } \\
\text { [26] }\end{array}$ & $2010-2011$ & 67.9 & 2047 & $50-69$ years & 2 & $\begin{array}{l}\text { SR or medication use } \\
\text { or } \mathrm{HbA} A c^{c}\end{array}$ & $\begin{array}{l}\text { Diagnosed } \\
\text { Undiagnosed } \\
\text { Total }\end{array}$ & $\begin{array}{l}6.8^{*} \\
7.1^{*} \\
11.1^{*}\end{array}$ & $\begin{array}{l}3.1^{*} \\
2.7^{*} \\
6.0^{*}\end{array}$ & $\begin{array}{l}5.0(4.1-6.0) \\
3.5(2.8-4.4) \\
8.5(7.4-8.8)\end{array}$ \\
\hline
\end{tabular}

${ }^{*} p$ for difference $<0.05$

${ }^{a} S R$ self-reported data; ${ }^{b}$ Fasting plasma glucose (American Diabetes Association criteria (ADA, 1997); ${ }^{C} \mathrm{HbA1C}$ (ADA, 2010) 


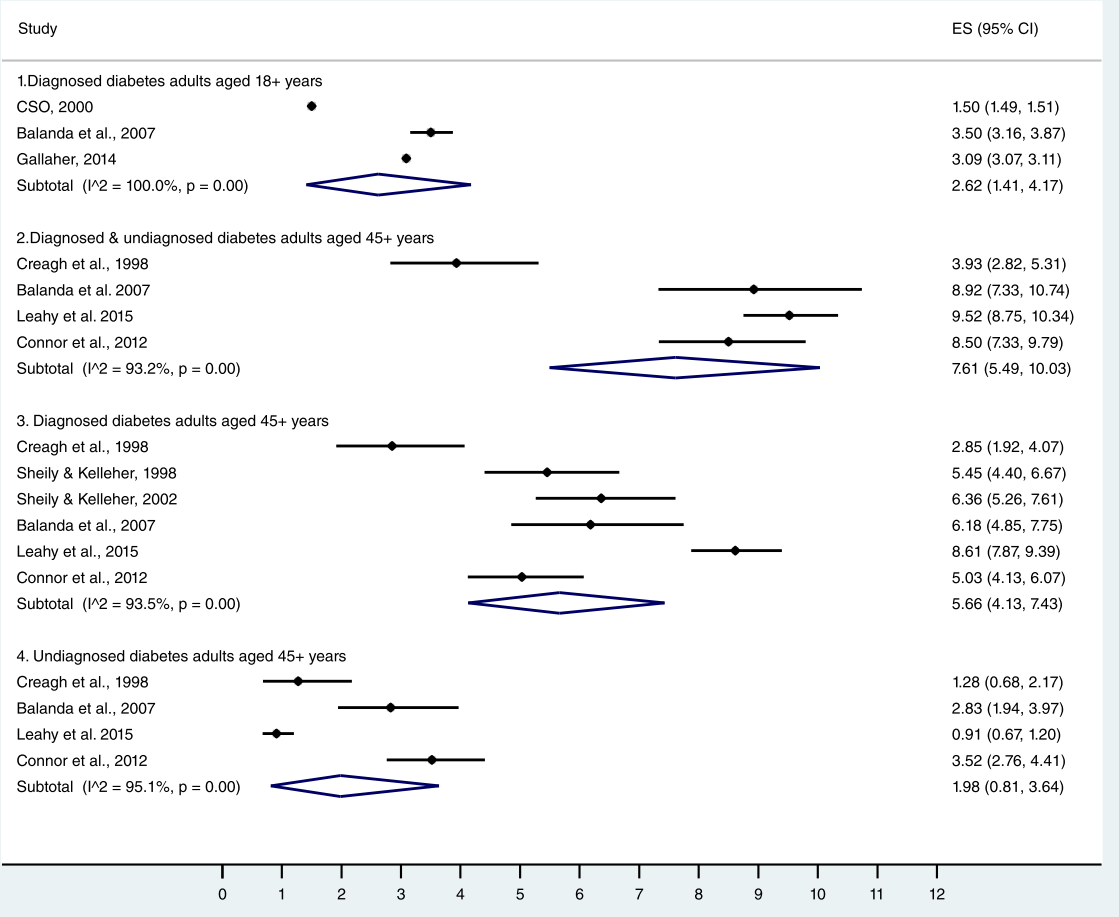

Fig. 2 Forest plot of individual and summary diabetes prevalence estimates of included studies

prevalence among men aged 40 to 69 years between 1998 (3.5 \% [95 \% CI: 3.4-3.6 \%]) and 2015 (6.6 \% [95 \% CI: 6.5-6.7\%]; $\left.p_{\text {trend }}<0.001\right)$. The prevalence of diabetes also increased among women in the same age group over the same time period (1998-2.5\% [95 \% CI: $2.4-$
$2.5 \%$ ] to $2015-4.2 \%$ [95 \% CI: 4.1-4.3\%]; $p_{\text {trend }}$ $<0.001)$. In those aged 70 years and over, an upward trend in prevalence among both men (1998-8.2\% [95 \% CI: 8.0-8.3 \%] to 2015- $15.1 \%$ [95 \% CI: $14.8-$ $15.2 \%])$ and women (1998- $4.7 \%$ [95 \% CI: 4.5-4.8\%]

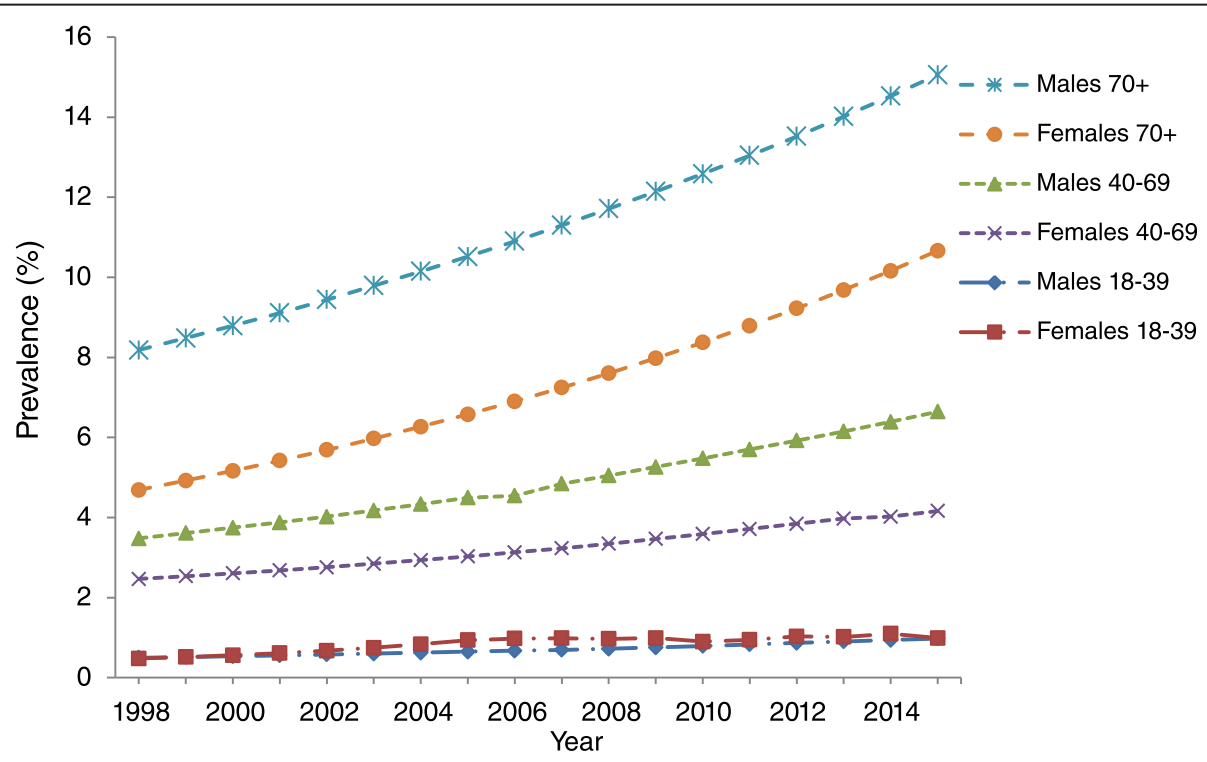

Fig. 3 Prevalence of self-reported doctor diagnosed diabetes among adults in Rol, 1998-2015 
to $2015-10.7 \%$ [95 \% CI: $10.5-10.8 \%$ ]) was also observed; $p_{\text {trend }}<0.001$.

\section{Prevalence of microvascular and macrovascular complications}

Table 4 describes the prevalence of microvascular and macrovascular complications in each included study. Five out of seven studies reported the prevalence of retinopathy [27, 29-31, 33]. Among people with type 2 diabetes, a population based study reported the prevalence of diabetic retinopathy to be $8.5 \%$ in 2009-2011 [30]; a regional study, carried out among primary care patients, found a higher prevalence of $24.8 \%$ [31]; however this estimate included patients with type 1 and 2 diabetes and was based on objective data. A similar estimate (25.6\%) was reported in a comparable cohort of primary care patients in a different region [33].

In terms of diabetes-related neuropathy, a divergence in the reported prevalence between studies was also observed. Data from 12 primary care centres in the West of Ireland indicated a prevalence of past documented neuropathy to be $3 \%$ [30]. On the other hand, a populationbased study reported a prevalence of $14.6 \%$ [32]. These patients had similar average duration since diagnosis (7.8 years [30] vs. 5.0 years [32]); however, the latter estimate was based on self-reported data. Prevalence rates for leg amputations were $1.7 \%$ among primary care patients with diabetes [30]. In contrast, the prevalence of nontraumatic lower leg amputation was lower (0.2\%) in a population-based study which utilised national hospital discharge data [29].

With reference to nephropathy, prevalence among those with type 2 diabetes was similar in two studies [31, 32]. In the three studies presenting data on macrovascular complications, a marked difference in prevalence was observed. A primary care audit reported a prevalence of $3.5 \%$ in patients with type 1 and 2 diabetes [34]. In contrast, among those with type 2 diabetes, a population based study reported a higher prevalence of $15.1 \%$ [32].

\section{Discussion}

This systematic review is the first study to compile all available evidence reporting the prevalence of diabetes (diagnosed and undiagnosed) and related complications (microvascular and macrovascular) among adults in Ireland between 1998 and 2015. Fifteen studies (eight describing diabetes prevalence and seven describing complication prevalence) were included.

Similar to other systematic reviews [35-37]; comparability between studies was limited due to differences in study population, sampling methods and diagnostic criteria. Additionally, substantial statistical heterogeneity was detected between studies reporting the prevalence of diabetes; therefore our pooled estimates have to be interpreted with caution. Sensitivity analysis, based on study quality, lowered the heterogeneity of combined prevalence rates for undiagnosed and diagnosed diabetes among adults aged over 45 years. However, this may reflect variability between prevalence estimates rather than study quality. Trends in diabetes prevalence could not be explored by metaanalysis, therefore, original data from four populationbased national studies [16-19] were obtained to explore time trends in doctor diagnosed diabetes prevalence between 1998 and 2015. Over a seventeen year period, we observed an important increase in the national prevalence of self-reported diagnosed diabetes in Ireland.

Consistent with previous research [38-40] trends in the prevalence of self-reported diagnosed diabetes remained constant in adults aged 18 to 39 years, while an increasing prevalence was observed in the older age groups. We were unable to distinguish between the various types of diabetes in this review; however it can be assumed that type 2 diabetes is driving the increase in prevalence as it accounts for $90 \%$ of all diabetes cases [1,2]. The prevalence of diabetes was consistently higher in males compared to females. Evidence suggests that men are at a higher risk of developing type 2 diabetes as they develop diabetes at a lower BMI, are more predisposed to central fat deposition and are more prone to insulin resistance [41]. Therefore, men are more likely to develop type 2 diabetes in response to increasing levels of obesity [42]. On the other hand, the higher prevalence in the male population may reflect preferences in diagnostic methods. Evidence has highlighted that the prevalence of FPG diagnosed diabetes is higher among men, whereas women are more commonly diagnosed by a 2-h plasma glucose test [43]. While it is not possible to determine the method of diabetes diagnosis in this review; it is important to consider how these gender differences may influence diagnosed diabetes prevalence estimates over time.

Similar to diagnosed diabetes, trends in the prevalence of undiagnosed diabetes could not be explored by metaanalysis as only two nationally representative studies had relevant data [11, 25]. The prevalence of undiagnosed diabetes, based on HbA1c, decreased from $2.8 \%$ in 2007 to $0.9 \%$ in $2009-2011$ among adults aged $\geq 45$ years and $\geq 50$ years, respectively. While the prevalence of diagnosed diabetes increased from $6.1 \%$ in 2007 [11] to $8.6 \%$ in 2009-2011 [25]. This shift from undiagnosed to diagnosed diabetes prevalence has also been observed in a study carried out in Germany [10]. This decrease in undiagnosed diabetes prevalence may be attributable to earlier detection of diabetes [10]. In Ireland, screening high risk patients for type 2 diabetes has been encouraged since the introduction of national guidelines for diabetescare in 2002 [44]. Another study based on 29144 adults aged 45-75 years with private health insurance, reported the prevalence of undiagnosed diabetes to be $1.8 \%$ in 
Table 4 Prevalence of microvascular and macrovascular complications in included studies, 2003-2011

\begin{tabular}{|c|c|c|c|c|c|c|c|c|c|c|}
\hline Author & $\begin{array}{l}\text { Year of } \\
\text { study }\end{array}$ & $\begin{array}{l}\text { Response } \\
\text { rate (\%) }\end{array}$ & $\begin{array}{l}\text { Sample } \\
\text { size }\end{array}$ & Age & $\begin{array}{l}\text { Diabetes } \\
\text { type }\end{array}$ & $\begin{array}{l}\text { Time since } \\
\text { diabetes } \\
\text { diagnosis }\end{array}$ & Data source & Diagnostic method & Type of complication & $\begin{array}{l}\text { Prevalence (\%) } \\
\text { Total }\end{array}$ \\
\hline $\begin{array}{l}\text { Kelliher } \\
\text { et al. [28] }\end{array}$ & 2003 & - & 6826 & Adults & All & - & National blind registry & $\begin{array}{l}\text { Visual acuity of }<6 / 60 \text { in } \\
\text { better eye/visual field } \\
\text { subtending angle of } \\
20^{\circ} /<\text { less }\end{array}$ & Blindness due to diabetic retinopathy & 4.7 \\
\hline $\begin{array}{l}\text { Buckley } \\
\text { et al. [29] }\end{array}$ & 2009 & - & 723,551 & 20 years & All & - & $\begin{array}{l}\text { Hospital discharge } \\
\text { data }\end{array}$ & ICD-10 codes & Non-traumatic lower leg amputation & 0.2 \\
\hline $\begin{array}{l}\text { Marsden } \\
\text { et al. [34] }\end{array}$ & $\begin{array}{l}\text { Nov 2008- } \\
\text { March } 2009\end{array}$ & 72 & 1071 & $\begin{array}{l}63 \text { years } \\
(\text { sd 13) }\end{array}$ & $\begin{array}{l}\text { T1: } 7.5 \% \\
\text { T2: } 92.3 \%\end{array}$ & 15 years & $\begin{array}{l}\text { Electronic \& paper } \\
\text { clinical notes \& referral } \\
\text { letters }\end{array}$ & $\begin{array}{l}\text { - } \\
\text { Risk classification score } \\
\text { ACR } 2.5-25 \\
\text { ACR }>25 \\
- \\
- \\
-\end{array}$ & $\begin{array}{l}\text { Diabetic retinopathy } \\
\text { Foot ulcer } \\
\text { Microalbuminuria } \\
\text { Proteinuria } \\
\text { Myocardial Infarction } \\
\text { Heart Failure } \\
\text { Transient Ischemic Attack } \\
\text { Stroke } \\
\text { Total macrovascular }\end{array}$ & $\begin{array}{l}24.8 \\
2.5 \\
32.1 \\
6.0 \\
0.4 \\
0.3 \\
1.5 \\
0.5 \\
3.5\end{array}$ \\
\hline $\begin{array}{l}\text { Hurley } \\
\text { et al. [30] }\end{array}$ & $\begin{array}{l}\text { Feb 2008- } \\
\text { Sept } 2009\end{array}$ & 68 & 563 & $\begin{array}{l}64 \text { years } \\
\text { (sd 13.4) }\end{array}$ & $\begin{array}{l}\text { T1: } 10 \% \\
\text { T2: } 90 \%\end{array}$ & $\begin{array}{l}7.7(8.2) \\
\text { years }\end{array}$ & $\begin{array}{l}\text { Clinical foot examination } \\
\text { \& practice medical records }\end{array}$ & $\begin{array}{l}\text { Scottish Intercollegiate } \\
\text { Guidelines Network risk } \\
\text { stratificationsystem \& } \\
\text { previous doctor diagnosis }\end{array}$ & $\begin{array}{l}\text { Documented diabetic neuropathy } \\
\text { Foot ulceration } \\
\text { Past amputation } \\
\text { Neuropathy symptoms at examination }\end{array}$ & $\begin{array}{l}3.0 \\
3.7 \\
1.7 \\
32\end{array}$ \\
\hline $\begin{array}{l}\text { Farrell \& } \\
\text { Moran [31] }\end{array}$ & 2010 & - & 309 & - & $\mathrm{T} 2$ & - & Chart review & - & $\begin{array}{l}\text { Diabetic retinopathy } \\
\text { Neuropathy } \\
\text { Peripheral vascular disease } \\
\text { Chronic kidney disease } \\
\text { Cerebrovascular disease }\end{array}$ & $\begin{array}{l}6.5 \\
12.3 \\
12.9 \\
5.5 \\
5.2\end{array}$ \\
\hline $\begin{array}{l}\text { Tracey } \\
\text { et al. [32] }\end{array}$ & 2009-2011 & 62 & 655 & 50 years & $\mathrm{T} 2$ & $\begin{array}{l}5(\mathrm{IQR} 3-10) \\
\text { years }\end{array}$ & $\begin{array}{l}\text { SR previous doctor } \\
\text { diagnosis }\end{array}$ & - & $\begin{array}{l}\text { Diabetic retinopathy } \\
\text { Neuropathy } \\
\text { Leg ulcer } \\
\text { Nephropathy } \\
\text { Proteinuria } \\
\text { Total macrovascular }\end{array}$ & $\begin{array}{l}8.2(6.2-10.9) \\
14.6(11.4-18.2) \\
4.2(2.8-6.4) \\
5.1(3.4-7.6) \\
6.1(4.3-8.6) \\
15.1(12.2-18.4)\end{array}$ \\
\hline $\begin{array}{l}\text { McHugh } \\
\text { et al. [33] }\end{array}$ & 2011 & $\begin{array}{l}\text { GP }=94 \% ; \\
\text { Screening } \\
\text { uptake = } 43 \%\end{array}$ & 1542 & $\begin{array}{l}65 \text { years } \\
\text { (sd 13) }\end{array}$ & $\begin{array}{l}\text { T1: } 4.9 \% \\
\text { T2: } 85.6 \%\end{array}$ & - & $\begin{array}{l}\text { Eye examination \& clinical } \\
\text { records }\end{array}$ & $\begin{array}{l}\text { Fundus } 45^{\circ} \text { digital } \\
\text { PASA-approved camera }\end{array}$ & $\begin{array}{l}\text { Background (R1) } \\
\text { Pre proliferative (R2) } \\
\text { Proliferative (R3) } \\
\text { Any diabetic retinopathy }\end{array}$ & $\begin{array}{l}21.5(19.5-23.6) \\
3.4(2.6-4.5) \\
0.7(0.4-1.3) \\
25.6(23.5-27.9)\end{array}$ \\
\hline
\end{tabular}


2009-2012 [45]. However this estimate was derived from FPG; evidence suggests that the use of HbAlc may underestimate diabetes prevalence compared with estimates using FPG $[38,43,46]$.

The prevalence of diabetes complications varied substantially between studies therefore comparisons between studies have to be interpreted with caution. These variations may be attributable to differences in disease duration or study population (type 1 and type 2 diabetes vs. type 2 diabetes), study setting (primary care vs. population-based) or heterogeneity in the criteria used to diagnose macrovascular and microvascular complications. Objective data describing the national prevalence of diabetic retinopathy was not available however, regional data on diabetic retinopathy showed that approximately $25 \%$ of primary care patients with type 1 and type 2 diabetes had been diagnosed with this condition [33,34]. This estimate is higher than a previous hospital-based study based on patients with type 2 diabetes (14.8\%) [47] and primary care data from the UK (19.6\%) [48] but lower than global prevalence estimates (34.6\%) [49]. Though, caution has to be applied when interpreting the results as both regional studies included in this review reported a low uptake rate of retinopathy screening at approximately $50 \%$ [33, 34]. Additionally, characteristics between attenders and nonattenders were not compared in either study; hence it is possible that there were systematic differences between the two groups. Healthier people are more likely to participate in research; therefore the prevalence of diabetic retinopathy may have been underestimated. As a national screening programme for diabetic retinopathy was introduced in 2013 [50], future estimates based on this national programme may be more reliable.

\section{Limitations}

The strengths and limitations of this systematic review should be noted. Both peer-reviewed articles and estimates detailed in the grey literature were included to limit the impact of publication bias. Original data from four national studies were obtained so trends in diagnosed diabetes prevalence could be examined over a 17 year period. Although response rates were below the optimal rate of $70 \%$, the representativeness of each study has been demonstrated previously $[18,51]$, so it can be assumed that the results presented can be generalised to the Irish population.

However, several limitations need to be acknowledged. Firstly, studies included in this review were of moderate to high quality; however, six of the included studies relied on self-reporting to determine the prevalence of diagnosed diabetes and one study relied on self-reporting to determine the prevalence of diabetes related complications. This approach is prone to misclassification bias which can result in an inaccurate estimation of prevalence
[52]. When compared to medical records, data from selfreport have been shown to underestimate the prevalence of diabetic retinopathy [53]. However, moderate to high levels of agreement between diabetes prevalence and selfreport have been shown in several studies [54-56]. Although only data on self-reported diabetes were available, results from trend analysis are in line with other developed countries. Secondly, without the inclusion of undiagnosed diabetes in our trend analysis, we acknowledge that diabetes prevalence is underestimated. Finally, significant increases in diagnosed diabetes prevalence were observed over time but these increases may be attributed to heightened awareness among patients, changes in clinical practices, including increased screening for type 2 diabetes, and better survival rates for patients with diabetes [57]. However, there is a lack of data on mortality rates among people with diabetes in Ireland; therefore it is not possible to determine whether our increasing trends in prevalence are due to improved health outcomes in those with diabetes.

\section{Conclusion}

This review provides the first comprehensive overview of the burden of diabetes in Ireland. In the absence of a national diabetes register, the findings in this review provide a robust estimate of the trends in prevalence of doctor diagnosed diabetes among the adult population in Ireland. Findings from this review are in accordance with the Euro Diabetes Index (2014) [12]; there is a lack of information relating to the prevalence of undiagnosed diabetes, macrovascular and microvascular complications. Interpretation of available data was limited due to inconsistencies in reporting, limited availability of objective data and standardisation in diagnostic criteria. We suggest that the true burden of diabetes in Ireland is underestimated [58]. In 2010, the National Clinical Programme in Diabetes was established to improve and standardise patient care in Ireland [59]. Reliable baseline data are needed to monitor improvements in care over time at a national level. Therefore, we suggest that a comprehensive national diabetes register is urgently needed in Ireland.

\section{Additional files}

Additional file 1: Electronic search strategies for articles. (DOCX $11 \mathrm{~kb})$

Additional file 2: Critical appraisal checklist for studies reporting prevalence data. (DOCX $25 \mathrm{~kb}$ )

Additional file 3: Sensitivity analysis based on high quality studies. (DOCX $16 \mathrm{~kb}$ )

Competing interest

The authors declare that they have no competing interests.

Authors' contributions

MLT, MG, PMK, APF conceived and designed the study. MLT, MG, KON researched data. MLT analysed the data. MLT wrote the manuscript. PMK, SMMc, CMB, APF, 
RJC, KON, APF reviewed the manuscript. MLT edited the manuscript. MLT, MG, KON, PMK, SMMc, CMB, APF, RJC approved final manuscript.

\section{Acknowledgements}

Marsha Tracey and Professor Patricia Kearney are funded by the Health Research Board Leadership Award in Diabetes (RL/2013/7). Dr. Sheena Mc Hugh is funded by the Centre for Ageing and Development Research in Ireland (CARDI) Leadership Fellowship. MLT would like to thank Professor John Browne, University College Cork for advice on methodology.

\section{Author details}

'Department of Epidemiology and Public Health, University College Cork, Western Gateway Building, Cork, Republic of Ireland. ${ }^{2}$ Department of Medicine, Royal College of Surgeons, Dublin, Republic of Ireland. ${ }^{3}$ Department of Public Health, Heath Service Executive (HSE) South, Cork, Republic of Ireland. ${ }^{4}$ Department of Endocrinology, St. Vincent's University Hospital, Dublin, Republic of Ireland.

\section{Received: 6 July 2015 Accepted: 3 February 2016 \\ Published online: 09 February 2016}

\section{References}

1. Zimmet P, Alberti KG, Shaw J. Global and societal implications of the diabetes epidemic. Nature. 2001;414:782-7.

2. International Diabetes Federation. IDF Diabetes Atlas, 6th edn. International Diabetes Federation. Brussels, Belgium: 2013.

3. Danaei G, Finucane MM, Lu Y, Singh GM, Cowan MJ, Paciorek CJ, et al. National, regional, and global trends in fasting plasma glucose and diabetes prevalence since 1980: systematic analysis of health examination surveys and epidemiological studies with 370 country-years and 2.7 million participants. Lancet. 2011:378:31-40.

4. Kearns K, Dee A, Fitzgerald A, Doherty E, Perry IJ. Chronic disease burden associated with overweight and obesity in Ireland: the effects of a small BMI reduction at population level. BMC Public Health. 2014;14:143.

5. International Diabetes Federation. Diabetes Atlas, 2000, 1st edn International Diabetes Federation. Brussels, Belgium: 2000.

6. Venkat Narayan KM, Greg EW, Fagot-Campagna A, Engelgau MM, Vinicor F. Diabetes- a common, growing, serious, costly and potentially preventable public health problem. Diabetes Res Clin Pract. 2000;50:S77-S84.

7. Garcia MJ, McNamara PM, Gordon T, Kannell WB. Morbidity and mortality in diabetics in the framingham population: Sixteen year follow-up study. Diabetes. 1974;23:105-11.

8. Roper NA, Bilous RW, Kelly WF, Unwin NC, Connolly VM. Cause-specific mortality in a population with diabetes: South Tees Diabetes Mortality Study. Diabetes Care. 2002;25:43-8.

9. Tamayo T, Rosenbauer J, Wild SH, Spijkerman AM, Baan C, Forouhi NG, et al. Diabetes in Europe: an update. Diabetes Res Clin Pract. 2014;103:206-17.

10. Heidemann C, Du Y, Paprott R, Haftenberger M, Rathmann W, Scheidt-Nave C. Temporal changes in the prevalence of diagnosed diabetes, undiagnosed diabetes and prediabetes: findings from the German health interview and examination surveys in 1997-1999 and 2008-2011. Diabetic Med. 2015. doi:10.1111/dme.13008

11. Balanda KP, Buckley CM, Barron SJ, Fahy LE, Madden JM, Harrington JM, et al. Prevalence of diabetes in the Republic of Ireland: Results from the National Health Survey (SLAN) 2007. PLoS One. 2013:8:e78406.

12. Garrofé B, Björnberg A, Yung Phang A. Euro diabetes index 2014. http://www.healthpowerhouse.com/files/EDI-2014/EDI-2014-report.pdf. Accessed 21 Oct 2014.

13. Moher D, Liberati A, Tetzlaff J, Altman DG. Preferred reporting items for systematic reviews and meta-analyses: the PRISMA statement. Ann Intern Med. 2009;151:264-9.

14. Munn Z, Moola S, Riitano D, Lisy K. The development of a critical appraisal tool for use in systematic reviews addressing questions of prevalence. Int Health Policy Manag. 2014:3:123-8.

15. DerSimonian R, Laird N. Meta-analysis in clinical trials. Control Clin Trials. 1986;7:177-88.

16. Department of Health and Children. Survey on Lifestyle and Attitude to Nutrition (SLÁN). Galway: NUIG, Centre for Health Promotion Studies; 1998.

17. Department of Health and Children. Survey on Lifestyle and Attitude to Nutrition (SLÁN). Galway: NUIG, Centre for Health promotion Studies; 2002.
18. Morgan K, McGee H, Watson D, Perry IJ, Barry M, Shelley E, et al. SLAN 2007: survey of lifestyle, attitudes \& nutrition in Ireland: main report. Dublin: Department of Health and Children. http://epubs.rcsi.ie/cgi/viewcontent. cgi?article=1002\&context=psycholrep. Accessed 10 January 2015

19. Kearney PM, Cronin H, O'Regan C, Kamiya Y, Savva GM, Whelan B, et al. Cohort profile: The Irish longitudinal study on ageing. Int J Epidemiol. 2011:40:877-84.

20. Kenny R, Whelan B, Cronin H, Kamiya Y, Kearney P, O'Regan C, et al. The design of the Irish longitudinal study on ageing. Dublin: Trinity College Dublin; 2010.

21. Census of Population Interactive Tables, 2014. http://www.cso.ie/px/pxeirestat/ Database/eirestat/Annual\%20Population\%20Estimates/

Annual\%20Population\%20Estimates_statbank. asp?SP=Annual\%20Population\%20Estimates\&Planguage $=0$. Accessed 2 March 2015

22. Shiely F, Kelleher C. Older people in Ireland: A profile of health status, lifestyle and socio-economic factors from SLÁN: National Council on Ageing and Older People Dublin; 2004

23. Creagh D, Neilson S, Collins A, Colwell N, Hinchion R, Drew C, et al. Established cardiovascular disease and CVD risk factors in a primary care population of middle-aged Irish men and women. Ir Med J. 2002;95:298-301.

24. Gallagher N, Bennett K, Smith SM, O'Reilly D. Impact of two different health systems on the burden of type 2 diabetes. J Health Serv Res Policy. 2014;19:69-76.

25. Leahy S, O'Halloran A, O'Leary N, Healy M, McCormack M, Kenny R, et al. Prevalence and correlates of diagnosed and undiagnosed type 2 diabetes mellitus and pre-diabetes in older adults: Findings from the Irish Longitudinal Study on Ageing (TILDA). Diabetes Res Clin Prac. 2015;110(3):241-9.

26. OConnor JM, Millar SR, Buckley CM, Kearney PM, Perry IJ. The prevalence and determinants of undiagnosed and diagnosed type 2 diabetes in middle-aged irish adults. PLoS One. 2013:8(11):e80504.

27. Central Statistics Office. Quarterly National Household Survey, 2001. Module on Health, Quarter 3. 2001. http://www.cso.ie/en/media/csoie/releases publications/documents/labourmarket/2001/qnhs_healthqtr32001.pdf. Accessed 14 March 2014

28. Kelliher C, Kenny D, O'Brien C. Trends in blind registration in the adult population of the Republic of Ireland 1996-2003. Br J Ophthalmol. 2006:90:367-71.

29. Buckley CM, O'Farrell A, Canavan RJ, Lynch AD, De La Harpe DV, Bradley CP, et al. Trends in the incidence of lower extremity amputations in people with and without diabetes over a five-year period in the Republic of Ireland. PLoS One. 2012;7:e41492.

30. Hurley L, Kelly L, Garrow AP, Glynn LG, Mclntosh C, Alvarez-lglesias A, et al. A prospective study of risk factors for foot ulceration: The West of Ireland Diabetes Foot Study. QJM. 2013;106:1103-10.

31. Farrell C, Moran J. Comparison of comorbidities in patients with prediabetes to those with diabetes mellitus type 2. Ir Med J. 2014;107:72-4.

32. Tracey ML, McHugh SM, Buckley CM, Canavan RJ, Fitzgerald AP, Kearney PM The prevalence of Type 2 diabetes and related complications in a nationally representative sample of adults aged 50 and over in the Republic of Ireland. Diabet Med. 2015. doi:10.1111/dme.12845.

33. McHugh SM, Buckley CM, Murphy K, Doherty S, O'Keeffe G, Alade J, et al. Quality-assured screening for diabetic retinopathy delivered in primary care in Ireland: an observational study. Br J Gen Pract. 2013;63:e134-40.

34. Marsden P, Brennan C, McHugh SM, Harkins V. Audit Report of the HSE Midland Diabetes StructuredCare Programme. Department of Public Health. Health Service Executive Dublin Mid-Leinster. 2010.

35. Pereira M, Carreira H, Lunet N, Azevedo A. Trends in prevalence of diabetes mellitus and mean fasting glucose in Portugal (1987-2009): a systematic review. Public Health. 2014;128:214-21.

36. Bos $\mathrm{M}$, Agyemang C. Prevalence and complications of diabetes mellitus in Northern Africa, a systematic review. BMC Public Health. 2013;13:387.

37. Hall V, Thomsen RW, Henriksen O, Lohse N. Diabetes in Sub Saharan Africa 1999-2011: epidemiology and public health implications. A systematic review. BMC Public Health. 2011;11:564

38. Hamer M, Kengne AP, Batty GD, Cooke D, Stamatakis E. Temporal trends in diabetes prevalence and key diabetes risk factors in Scotland, 2003-2008. Diabet Med. 2011:28:595-8.

39. Lipscombe LL, Hux JE. Trends in diabetes prevalence, incidence, and mortality in Ontario, Canada 1995-2005: a population-based study. Lancet. 2007;369:750-6

40. Bonaldi C, Vernay M, Roudier C, Salanave B, Oleko A, Malon A, et al. A first national prevalence estimate of diagnosed and undiagnosed diabetes in 
France in 18- to 74-year-old individuals: the French Nutrition and Health Survey 2006/2007. Diabet Med. 2011;28:583-9.

41. Sarwar N, Gao P, Seshasai SR, Gobin R, Kaptoge S, Di Angelantonio E, et al. Diabetes mellitus, fasting blood glucose concentration, and risk of vascular disease: a collaborative meta-analysis of 102 prospective studies. Lancet. 2010;375:2215-22.

42. Sattar N. Gender aspects in type 2 diabetes mellitus and cardiometabolic risk. Best Pract Res Clin Endocrinol Metab. 2013;27:501-7.

43. Cowie CC, Rust KF, Byrd-Holt DD, Gregg EW, Ford ES, Geiss LS, et al. Prevalence of diabetes and high risk for diabetes using $\mathrm{A} 1 \mathrm{C}$ criteria in the U.S. population in 1988-2006. Diabetes Care. 2010;33:562-8.

44. Clarke A. Diabetes care: Securing the future. Action plan for implementation of the St. Vincent declaration. Dublin: Diabetes Service Development Group: 2002.

45. Sinnott M, Kinsley BT, Jackson AD, Walsh C, O'Grady T, Nolan JJ, et al. Fasting plasma glucose as initial screening for diabetes and prediabetes in Irish adults: The Diabetes Mellitus and Vascular Health Initiative (DMVhi). PLoS One. 2015;10:e0122704.

46. Juarez DT, Demaris KM, Goo R, Mnatzaganian CL, Wong Smith H. Significance of $\mathrm{HbA}(1 \mathrm{c})$ and its measurement in the diagnosis of diabetes mellitus: US experience. Diabetes Metab Syndr Obes. 2014;7:487-494.

47. Nolan JJ, O'Halloran D, McKenna TJ, Firth R, Redmond S. The cost of treating type 2 diabetes (CODEIRE). Ir Med J. 2006;99:307-10.

48. Ruta LM, Magliano DJ, Lemesurier R, Taylor HR, Zimmet PZ, Shaw JE. Prevalence of diabetic retinopathy in Type 2 diabetes in developing and developed countries. Diabet Med. 2013:30:387-98.

49. Yau JW, Rogers SL, Kawasaki R, Lamoureux EL, Kowalski JW, Bek T, et al. Global prevalence and major risk factors of diabetic retinopathy. Diabetes Care. 2012;35:556-64.

50. Diabetic RetinaScreen. The National Diabetic Retinal Screen Programme. 2015. http://www.diabeticretinascreen.ie/. Accessed 12 Nov 2014.

51. Savva GM. In fifty plus in Ireland 2011: First results from the Irish longitudinal study on ageing. Dublin: Trinity College Dublin; 2011.

52. Critchfield T, Tucker J, Vuchinich R. Self-report methods. In: Lattal K, Perone M, editors. Handbook of research methods in human operant behavior. US: Springer; 1998. p. 435-70.

53. MacLennan PA, McGwin Jr G, Searcey K, Owsley C. Medical record validation of self-reported eye diseases and eye care utilization among older adults. Curr Eye Res. 2013;38:1-8.

54. Comino EJ, Tran DT, Haas M, Flack J, Jalaludin B, Jorm L, et al. Validating self-report of diabetes use by participants in the 45 and Up Study: a record linkage study. BMC Health Serv Res. 2013;13:481.

55. Okura Y, Urban LH, Mahoney DW, Jacobsen SJ, Rodeheffer RJ. Agreement between self-report questionnaires and medical record data was substantial for diabetes, hypertension, myocardial infarction and stroke but not for heart failure. J Clin Epidemiol. 2004;57:1096-103.

56. Galenkamp H, Huisman M, Braam AW, Schellevis FG, Deeg DJ. Disease prevalence based on older people's self-reports increased, but patientgeneral practitioner agreement remained stable, 1992-2009. J Clin Epidemiol. 2014:67:773-80.

57. Maruthur NM. The growing prevalence of type 2 diabetes: increased incidence or improved survival? Curr Diab Rep. 2013;13:786-94.

58. Kanavos $P$, van den Aardweg $S$, Schurer W. Diabetes expenditure, burden of disease and management in 5 EU countries. LSE Health and Social Care. 2012. http://www.lse.ac.uk/lsehealthandsocialcare/research/sehealth/mtrg/ Isediabetesreport26jan2012.pdf. Accessed 3 Nov 2014.

59. Health Service Executive. National Clinical Programme for Diabetes. 2010 http://www.hse.ie/eng/about/Who/clinical/natclinprog/diabetes programme/. Accessed 29 Aug 2014

\section{Submit your next manuscript to BioMed Central and we will help you at every step:}

- We accept pre-submission inquiries

- Our selector tool helps you to find the most relevant journal

- We provide round the clock customer support

- Convenient online submission

- Thorough peer review

- Inclusion in PubMed and all major indexing services

- Maximum visibility for your research

Submit your manuscript at www.biomedcentral.com/submit
Biomed Central 